UDC 661.8+66.067.8.081.3

R.V. Smotraiev, PhD, Assoc.Prof.,

E.O. Sorochkina, Master,

A.V. Dzuba, Bachelor,

Y.D. Galivets, PhD, Assoc.Prof.

Ukrainian State University of Chemical Engineering, 8 Gagarin Ave., 49005 Dnipropetrovsk, Ukraine; e-mail: kate_3110@mail.ru

\title{
SORBENTS BASED ON XEROGELS OF ZIRCONIUM, ALUMINUM AND MANGANESE OXYHYDROXIDES
}

\begin{abstract}
Р.В. Смотраєв, К.О. Сорочкіна, А.В. Дзюба, Ю.Д. Галівечь. Сорбенти на основі ксерогелів оксигідроксидів цирконію, алюмінію та марганцю. Актуальною проблемою водопостачання в світі, і в Україні зокрема, є високий рівень забруднення водних ресурсів і недостатній ступінь очищення питної води. Разом зі стічними водами промислових підприємств в навколишнє середовище скидається значна кількість забруднюючих речовин, у тому числі завислих частинок, сульфатів, сполук заліза, важких металів тощо. Мета: Метою дослідження є визначення впливу добавок іонів алюмінію і марганцю в процесі отримання сорбентів на основі оксигідроксиду цирконію на їх поверхневі і сорбційні властивості. Матеріали i методи: Сорбенти на основі ксерогелів оксигідроксидів цирконію, алюмінію і марганцю були отримані золь-гель методом в результаті гідролізу хлоридів металів (оксихлорид цирконію $\mathrm{ZrOCl}_{2}$, хлориди алюмінію $\mathrm{AlCl}_{3}$ і марганцю $\mathrm{MnCl}_{2}$ ) в присутності карбаміду. Результати: Досліджено поверхневі і сорбційні властивості сорбентів на основі ксерогелів оксигідроксидів цирконію, алюмінію і марганцю. Отримані ксерогелі характеризуються переважно рентгеноаморфною структурою і розвиненим гідроксильно-гідратним покривом. Двокомпонентні сорбенти на основі ксерогелів оксигідроксиду цирконію 3 добавками оксигідроксидів алюмінію $\left(\mathrm{a}_{\mathrm{S}}=537 \mathrm{~m}^{2} / \Gamma\right)$ і марганцю $\left(\mathrm{as}_{\mathrm{S}}=356 \mathrm{~m} 2 / \Gamma\right)$ мають

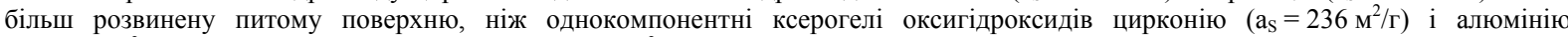
$\left(\mathrm{a}_{\mathrm{S}}=327 \mathrm{~m}^{2} / \Gamma\right)$. Максимальна сорбційна ємність за $\mathrm{SO}_{4}{ }^{2-}$-іонами у сорбента на основі ксерогелю оксигідроксидів цирконію і марганцю, який поглинає в 1,5 рази більше $\mathrm{SO}_{4}{ }^{2-}$-іонів, ніж промисловий аніоніт АН-221. Сорбенти на основі ксерогелю оксигідроксидів цирконію мають сорбційну ємність за іонами $\mathrm{Fe}^{3+}$ у $1,5 \ldots 2$ рази більшу за ємність промислового катіоніту КУ-2-8. Смність зразків за $\mathrm{Na}^{+}$-іонами становить 1,47...1,56 ммоль/г для всіх сорбентів. Висновки: 3 проведеного дослідження можна зробити висновок щодо ефективності запропонованого методу отримання сорбентів на основі ксерогелів оксигідроксидів цирконію, алюмінію і марганцю з подальшим їх застосуванням для видалення як полівалентних аніонів, так і важких металів 3 водних розчинів.

Ключові слова: ємність сорбенту, ксерогель, оксигідроксид алюмінію, оксигідроксид цирконію, оксигідроксид марганцю.
\end{abstract}

R.V. Smotraiev, E.O. Sorochkina, A.V. Dzuba, Y.D. Galivets. Sorbents based on xerogels of zirconium, aluminum and manganese oxyhydroxides. The actual problem of water supply in the world and in Ukraine, in particular, is a high level of pollution in water resources and an insufficient level of drinking water purification. With industrial wastewater, a significant amount of pollutants falls into water bodies, including suspended particles, sulfates, iron compounds, heavy metals, etc. Aim: The aim of this work is to determine the impact of aluminum and manganese ions additives on surface and sorption properties of zirconium oxyhydroxide based sorbents during their production process. Materials and Methods: The sorbents based on xerogels of zirconium, aluminum and manganese oxyhydroxides were prepared by sol-gel method during the hydrolysis of metal chlorides (zirconium oxychloride $\mathrm{ZrOCl}_{2}$, aluminum chloride $\mathrm{AlCl}_{3}$ and manganese chloride $\mathrm{MnCl}_{2}$ ) with carbamide. Results: The surface and sorption properties of sorbents based on xerogels of zirconium, aluminum and manganese oxyhydroxides were investigated. X-ray amorphous structure and evolved hydroxyl-hydrate cover mainly characterize the obtained xerogels. The composite sorbents based on xerogels of zirconium oxyhydroxide doped with aluminum oxyhydroxide $\left(a_{\mathrm{S}}=537 \mathrm{~m}^{2} / \mathrm{g}\right)$ and manganese oxyhydroxide $\left(\mathrm{a}_{\mathrm{S}}=356 \mathrm{~m}^{2} / \mathrm{g}\right)$ have more developed specific surface area than single-component xerogels of zirconium oxyhydroxide $\left(\mathrm{a}_{\mathrm{S}}=236 \mathrm{~m}^{2} / \mathrm{g}\right)$ and aluminum oxyhydroxide $\left(\mathrm{a}_{\mathrm{S}}=327 \mathrm{~m}^{2} / \mathrm{g}\right)$. The sorbent based on the xerogel of zirconium and manganese oxyhydroxides have the maximum $\mathrm{SO}_{4}{ }^{2-}$-ions sorption capacity. It absorbs 1.5 times more $\mathrm{SO}_{4}{ }^{2-}$-ions than the industrial anion exchanger AN-221. The sorbents based on xerogels of zirconium oxyhydroxide has the sorption capacity of $\mathrm{Fe}^{3+}$-ions that is $1.5 \ldots 2$ times greater than the capacity of the industrial cation exchanger $\mathrm{KU}-2-8$. The $\mathrm{Na}^{+}$-ions absorption capacity is $1.47 \ldots 1.56 \mathrm{mmol} / \mathrm{g}$ for each sorbent. Conclusions: Based on these data, it can be concluded that the proposed method is effective to produce of sorbents based on xerogels of zirconium, aluminum and manganese oxyhydroxides for further use them to remove both polyvalent anions and heavy metals from aqueous solutions.

Keywords: sorbent capacity, xerogel, aluminum oxyhydroxide, zirconium oxyhydroxide, manganese oxyhydroxide.

Introduction. The actual problem of water supply in the world and in Ukraine in particular, is a high level of water resources pollution and the low purification rate of drinking water [1]. Along with wastewater of metallurgy, coal-mining and are-mining industries, the significant amount of pollutants is discharged including suspended particles, sulfates, iron compounds, heavy metals, etc. The concentration of iron ions in such waste drains can achieve $300 \ldots 8000 \mathrm{mg} / \mathrm{dm}^{3}$ having $\mathrm{pH}=1.25 \ldots 3$ depending on industry type $[2,3]$. The draining of such type waste water leads to degradation of the

DOI 10.15276/opu.1.48.2016.14

(C) 2016 The Authors. This is an open access article under the CC BY license (http://creativecommons.org/licenses/by/4.0/). 
environmental ecological state and can have a negative impact on residential population health.

The sorbents based on metal oxides and hydroxides are used for water purification from heavy metals and polyvalent anions. These sorbents are obtained by chemical deposition of salts from inorganic salt aqueous solutions of these metals [4]. The special attention is paid to zirconium oxyhydroxide, which, due to advanced surface, chemical and mechanical stability and the evolved hydroxylhydrated cover is effective sorbent for water purification from various impurity [5]. The adding of additional ions of metals to initial solution of zirconium salt at the stage of zirconium oxyhydroxide receiving leads to improvement of sorbents properties. So, authors [6] have established that the presence of aluminum ions dopant promotes an increase the specific surface and the degree of hydroxylation of sorbent surface, the reduction of crystallites size and the increase of strength characteristics. It leads to improvement of sorption properties of received sorbents and the increase of removal efficiency for impurities during water purification. Also, the actual dopant is oxide/hydroxide of manganese which in water treatment process can act not only as sorption material, but also as the oxidation-reduction agent that increases the degree of water purification [7]. Thus, the development of sorbents containing two or more oxyhydroxides of metals gains the increasing value because such sorbents not only inherit properties of separate oxyhydroxides, but also get new due to synergetic effect [8].

The aim of this work is to determine the impact of aluminum and manganese ions additives on surface and sorption properties of zirconium oxyhydroxide based sorbents during their production process.

Materials and Methods. The sorbents based on xerogels of zirconium ( $\mathrm{ZOH})$, aluminum (AOH) and manganese $(\mathrm{MOH})$ oxyhydroxides were prepared by sol-gel method during the hydrolysis of metal chlorides (zirconium oxychloride $\mathrm{ZrOCl}_{2}$, aluminum chloride $\mathrm{AlCl}_{3}$ and manganese chloride $\mathrm{MnCl}_{2}$ ) in presence of a carbamide.

Hydrolysis was carried out in solutions of metals salts with the overall concentration $C_{M e}=1 \mathrm{~mol} / \mathrm{dm}^{3}$ at the temperature $\mathrm{T}=373 \mathrm{~K}$ and the following ratios of metals ions in solution: $\mathrm{Zr}: \mathrm{Al}=1: 0$ (sample 1), $\mathrm{Zr}: \mathrm{Al}=1: 3$ (sample 2), $\mathrm{Zr}: \mathrm{Al}=0: 1$ (sample 3), $\mathrm{Zr}: \mathrm{Mn}=10: 1$ (sample 4). The molar ratio of metals to carbamide for samples 1 and 4 is Me:K=1:3, for samples 2 and 3 $\mathrm{Me}: \mathrm{K}=1: 1.75$ were assumed on the basis of earlier conducted researches [9]. The offered technique of hydrolysis carrying out allows receiving the high-homogenized sols of the mixed composition. Sols were granulated by their dispergating in ammonium hydroxide solution. The received spherical granules were washed out using a vacuum filter with distilled water for full removal of impurity ions and then dried at the room temperature up to the constant weight.

For studying of surface characteristics of sorbents the X-ray phase analysis and IR-spectroscopy have been used. The X-ray phase analysis of the samples, which are dried up at $T=373 \mathrm{~K}$, was carried out with use of the DRON-2 diffractometer in monochromatic $\mathrm{Cu}-\mathrm{K}_{\alpha}$ radiation with the wavelength $\lambda=1.54056 \AA$ and the software «Match! $2 »$. IR-spectroscopic researches were conducted using the PerkinElmer Spectrum BX IR-Fourier spectrometer in the pass range mode of $4000 \ldots 400 \mathrm{~cm}^{-1}$ at the room temperature. Computer processing of spectra was carried out using the spectrometermanufactured software. The porous structure of sorbents has been studied using the BET method at adsorption of water vapor [9].

The sorption properties of sorbents were investigated in static conditions with the following parameters: room temperature; sorbent mass $m \approx 0.5 \mathrm{~g}$; the solution volume $V=50 \mathrm{~cm}^{3}$; sorption process duration -24 hours. To determine the capacity characteristics of sorbent the solutions of sodium hydroxide and sulphuric acid with concentration of 0.1 and $0.05 \mathrm{~mol} / \mathrm{dm}^{3}$, respectively, were used as standard solutions. Initial concentration of ferric chloride is $C\left(\mathrm{Fe}^{3+}\right)=7000 \mathrm{mg} / \mathrm{dm}^{3}$ $\left(125 \mathrm{mmol} / \mathrm{dm}^{3}\right)$. The chosen value of concentration allows to estimate the efficiency of received sorbents to remove of iron ions from acidulous industrial wastes. The process $\mathrm{Ff} \mathrm{Fe}^{3+}$ ions adsorption was carried out at initial $\mathrm{pH}=1 \ldots 3$. In such $\mathrm{pH}$ range the presence of following ionic forms of iron is possible: $\left[\mathrm{Fe}\left(\mathrm{H}_{2} \mathrm{O}\right)_{6}\right]^{3+},[\mathrm{FeOH}]^{2+}$ and $\left[\mathrm{Fe}(\mathrm{OH})_{2}\right]^{+}[10]$.

The total static exchange capacity (TSEC) of sorbents was calculated using formula: 


$$
\text { TSEC }=\frac{\left(C_{1} V_{1}-\frac{V_{1}}{V_{2}} C_{2} V\right) \cdot 100}{m_{S}(100-W)},
$$

where $C_{1}-$ initial $\mathrm{Na}^{+}, \mathrm{Fe}^{3+}$ and $\mathrm{SO}_{4}{ }^{2-}$ ions concentration in solutions of sodium hydroxide, ferric chloride and sulphuric acid, respectively, $\mathrm{mol} / \mathrm{dm}^{3}$;

$V_{1}$ - the volume of working solution, $\mathrm{cm}^{3}$;

$C_{2}$ - the concentration of titrant, $\mathrm{mol} / \mathrm{dm}^{3}$;

$V_{2}$ - the solution volume taken for titration, $\mathrm{cm}^{3}$;

$V$ - the volume of the titrant used for titration, $\mathrm{cm}^{3}$;

$m_{S}$ - the mass of sorbent, $\mathrm{g}$;

$W$ - the humidity of sorbent, $\%$.

Results. The conducted X-ray studies of sorbents have shown that the sample 3 has the signified crystal phase corresponding to $\gamma-\mathrm{Al}(\mathrm{OH})_{3}$ gibbsite with $\gamma-\mathrm{AlOOH}$ boehmite inclusions while other samples are poorly crystallized or in the X-ray amorphous state (Fig. 1).

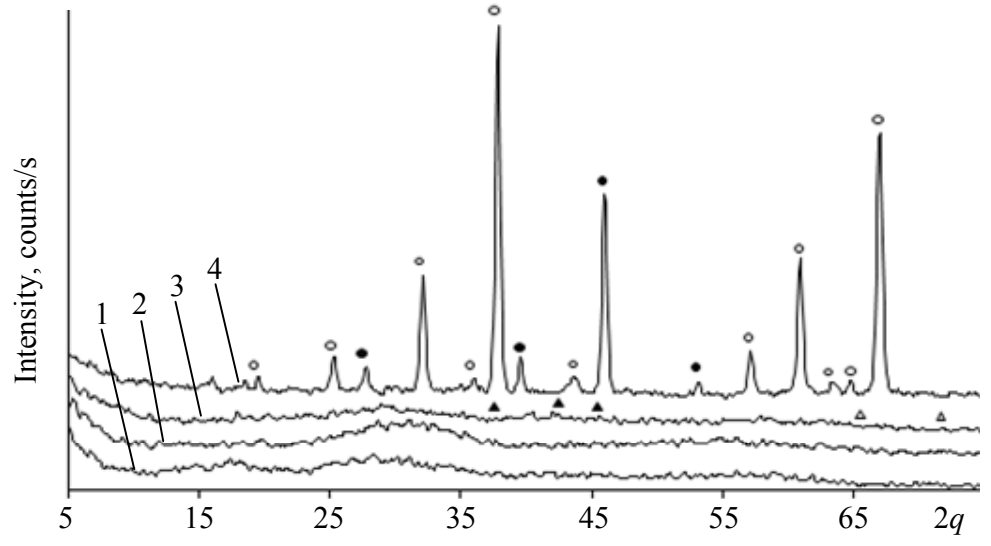

Fig. 1. X-ray diffraction pattern $f$ sorbents based on xerogels $\mathrm{Zr}$, Al and Mn oxyhydroxides:

1-sample 1; 2-sample 2; 3 - sample 3; 4-sample 4;

- boehmite $\gamma$-AlOOH; O - gibbsite $\gamma$ - $\mathrm{Al}(\mathrm{OH})_{3} ; \mathbf{\Delta}-\mathrm{Mn}_{3} \mathrm{O}_{4} ; \triangle$ - manganite $\gamma-\mathrm{MnOOH}$

The existence of the well crystallized phase in the sample 3 can be explained by the high $\mathrm{pH}$ value of the solution at the end of sol formation $(\mathrm{pH}=5.01)$, in comparison with samples 1,2 and 4 , where $\mathrm{pH}$ was 2,18, 3,3 and 2,3, respectively. Samples 2 and 4 have peaks with low intensity, that are specific for the crystal phases $\gamma-\mathrm{Al}(\mathrm{OH})_{3}, \gamma-\mathrm{AlOOH}$, manganite $\gamma-\mathrm{MnOOH}$ and $\mathrm{Mn}_{3} \mathrm{O}_{4}$, respectively. This testifies to preferential X-ray amorphy of sorbents based on $\mathrm{ZOH}$ with $\mathrm{Al}$ and $\mathrm{Mn}$ oxides impurity. Formation of $\mathrm{Mn}_{3} \mathrm{O}_{4}$ magnesium oxide occurs due to the partial oxidation of $\mathrm{Mn}(\mathrm{OH})_{2}$ magnesium hydroxide by air oxygen during the drying process of wet granules of sorbent. And, the formation of manganite demonstrates the high amount of water in sample during oxidation of $\mathrm{Mn}^{2+}$ ions [11].

The important characteristic of sorbents is presence of the evolved hydroxyl-hydrated cover and active sites by which the sorption of impurities from the water occurs. The data of IR-spectroscopic researches of received sorbents are presented in Fig. 2.

IR-spectra of all studied samples have the broad band with maximum at $3400 \mathrm{~cm}^{-1}$ and insignificant peak at $1630 \mathrm{~cm}^{-1}$. They characterize stretching vibrations $v(\mathrm{OH})$ of groups and molecules of crystallization water and the bending vibration $\delta\left(\mathrm{H}_{2} \mathrm{O}\right)$ which can be as the Bronsted acid sites. The small peak about $2300 \mathrm{~cm}^{-1}$ demonstrates the presence at surface of all sorbents, except sample 2, physically adsorbed molecule of carbon dioxide (physical bond character between sorbent surface and carbon dioxide is also confirmed by diffractograms where the peaks of metals carbonates are not detected).

For IR-spectrum of the sample 2 this peak is displaced to the area of $2011 \mathrm{~cm}^{-1}$ that corresponds to vibration of carbonyl group $\mathrm{C}=\mathrm{O}$, bonded with metal oxyhydroxide surface through bridging 
linkage. Forming of these bonds is possible due to adsorption of carbamide hydrolysis products at the Lewis acid sites [12]. Absorption bands with wavenumber of 1558, 1494, 1414 and $1340 \mathrm{~cm}^{-1}$ can be caused as by bending vibrations of hydroxylic $\delta(\mathrm{MOH})$ and hydroxyl groups, bonded with hydrogen bond and structured by water hydroxyls $\gamma(\mathrm{OH})$, as by symmetrical and asymmetrical vibrations of monodentate carbonate ion, which is formed due to sorption of carbon dioxide on the metal oxyhydroxide surface [13].

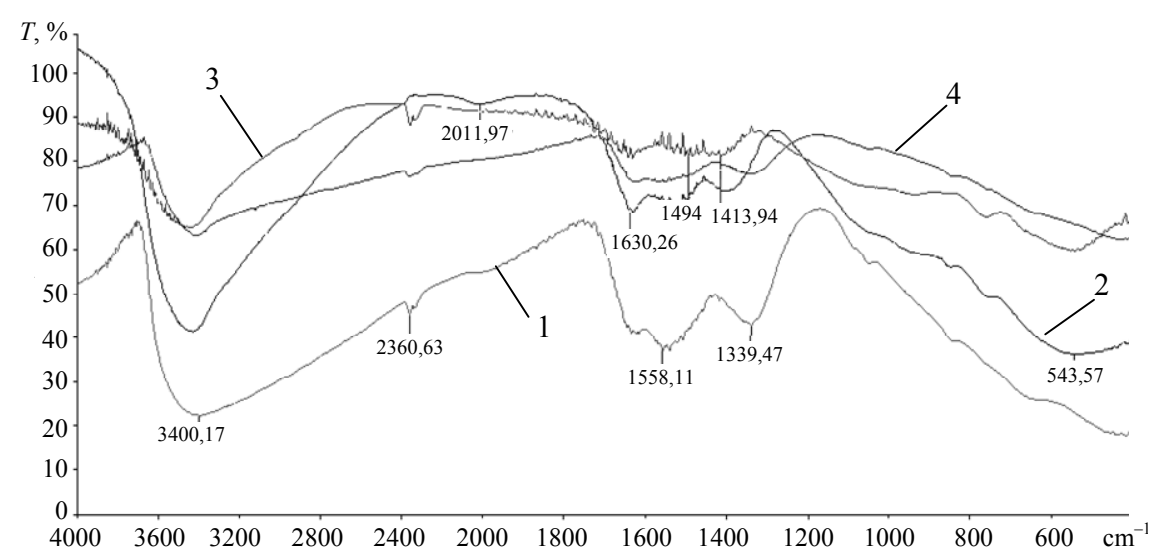

Fig. 2. IR-spectrum of sorbents: 1 - sample 1;2-sample 2; 3 - sample 3, 4-sample 4

The weak band in the range of $850 \ldots 840 \mathrm{~cm}^{-1}$ appertain to vibrations of $\mathrm{Zr}-\mathrm{O}$ groups at surface of sorbents containing Zirconium oxyhydroxide. The sample 3 has the absorption band with maximum at $542 \mathrm{~cm}^{-1}$ that corresponds to vibrations of Al-O. At IR-spectrum of sample 2 both peaks are shown. At the same time, the broad band around $670 \mathrm{~cm}^{-1}$, specific for vibrations of $\mathrm{Zr}-\mathrm{O}-\mathrm{Al}$, is missing. These indicates the formation of separate inclusions of metals oxyhydroxides which are not bonded by bridging linkage one to another.

Thus, during the sol-gel process initial salts of metals hydrolyze and form the homogeneous mixture of individual metals oxyhydroxides. The matrix of oxyhydroxides of aluminum or zirconium with evolved hydroxyl-hydrate cover forms during polymerization of this mixture. The sorbents matrix includes particles or molecules of impurity metals oxyhydroxides. Hydrocarbonate ions, produced during hydrolysis of carbamide, bond with Lewis and Brønsted active sites on surface of metals oxyhydroxides. The obtained data correlate well with the research results of acid-base properties of sorbents on the basis of the zirconium and aluminum oxyhydroxides which are carried out earlier [14] and confirm availability of both active sites of Bronsted and Lewis, because of which the processes of adsorption and ion exchange are generally proceed. Amphoteric properties of sorbents are confirmed with researches of their electrosurface properties [15]. The point of zero charge for samples on the basis of zirconium oxyhydroxide are within the range $\mathrm{pH}_{\mathrm{PZC}}=7.0 \pm 0.5$.

To determine the influence of sorbents composition on their porous structure, the specific surface and samples pore sizes were identified and given in table 1.

Table 1

The main characteristics of sorbents porous structure

\begin{tabular}{c|c|c|c|c}
\hline Sample No. & $S_{\text {surf }}, \mathrm{m}^{2} / \mathrm{g}$ & $V_{\text {total }}, \mathrm{cm}^{3} / \mathrm{g}$ & $r_{\text {prelevant }}, \AA$ & $r_{\text {average }}, \AA$ \\
\hline 1 & 236 & 0.113 & 7.40 & 8.05 \\
\hline 2 & 537 & 0.227 & 10.40 & 16.10 \\
\hline 3 & 327 & 0.171 & 5.40 & 12.11 \\
\hline 4 & 356 & 0.113 & 3.40 & 7.85 \\
\hline
\end{tabular}


The obtained sorbents have evolved specific surface and exceed analogs by this indicators [16]. At the same time, single-component sorbents (sample 1 and 3) have the smallest values of specific surface, and most likely, that caused by formation of closer package of homogeneous particles during drying and a lack of porous structure defects. Using the mix of $\mathrm{Zr}(\mathrm{IV})$ and $\mathrm{Al}(\mathrm{III})$ solution in hydrolysis leads to significant increase of specific surface and total pore volume of the obtained sorbent. That demonstrates the formation of more open and evolved porous structure. Addition the manganese salt to the solution leads to increase of specific surface by 1.5 times in comparison with pure ZOH and to reduction of the prevailing and average pore radiuses. Comparison of the data obtained by the BET method with results of XRD and IR-spectroscopy allows to offer the following mechanism of metals oxyhydroxides xerogels formation. During hydrolysis of the zirconium and aluminum salts mix, that have different $\mathrm{pH}$ values of the sedimentation start, initially the $\mathrm{Zr}(\mathrm{OH})_{4}$ particles are generated, which form the frame (matrix) of gel spheres during the sol-gel transition. The $\mathrm{AOH}$ particles with more hydrated gel layer are homogeneously located inside the framework. During the drying of such gel spheres more developed porous structure forms due to the different drying duration of $\mathrm{Zr}$ and $\mathrm{Al}$ oxyhydroxides particles and significant reduction of $\mathrm{Al}(\mathrm{OH})_{3}$ particles volume. During formation of the mixed sol of zirconium and manganese oxyhydroxides the $\mathrm{pH}$ difference of the sedimentation start is too great and ion concentration of manganese in solution is low. That leads to forming of structure of $\mathrm{ZOH}$ sol with $\mathrm{Mn}^{2+}$ ions dissolved in it. During the granulation process with $\mathrm{pH}=11$, inside the grid of zirconium oxyhydroxide gel the molecules or very small particles of manganese oxyhydroxide are formed. They fill the pores of future sorbent that leads to more close package of $\mathrm{ZOH}$ particles matrix.

To compare the sorption properties of the received samples with industrial ionites the total static exchange capacity of these materials has been determined towards to ions of $\mathrm{SO}_{4}{ }^{2-}, \mathrm{Na}^{+}$and $\mathrm{Fe}^{3+}$ ions, values of which are provided in table 2 .

Table 2

The humidity and the total static capacity of sorbents

\begin{tabular}{c|c|c|c|c}
\hline \multirow{2}{*}{ Sample No. } & \multirow{2}{*}{$W, \%$} & \multicolumn{3}{|c}{ TSEC, $\mathrm{mmol} / \mathrm{g}$} \\
\cline { 3 - 5 } & & $\mathrm{SO}_{4}^{2-}$ & $\mathrm{Na}^{+}$ & $\mathrm{Fe}^{3+}$ \\
\hline 1 & 11.82 & 0.62 & 1.56 & 4.98 \\
\hline 2 & 18.65 & 1.28 & 1.47 & 4.27 \\
\hline 3 & 16.81 & 1.74 & 1.56 & 3.29 \\
\hline 4 & 21.53 & 2.28 & 1.50 & 2.79 \\
\hline KU-2-8 & 48.00 & - & 2.40 & - \\
\hline AN-221 & 40.00 & 1.56 & - & -37 \\
\hline
\end{tabular}

The data presented in table 2 demonstrate that full static capacity of sorbents for sulfate ions falls, but for iron ions grows with increasing of zirconium oxyhydroxide content. In the same time full static capacity for sodium ions almost does not change. Sample 4, which based on xerogel zirconium oxyhydroxide doped by manganese oxyhydroxide demonstrated the maximum value of capacity towards sulfate ions that is almost $50 \%$ higher than the static capacity of industrial anion exchanger AN-221. All obtained sorbents have the capacity for sodium ions at $38 \%$ less in compare with the industrial cation exchanger $\mathrm{KU}-2-8$, but their capacity for iron ions at $40 \ldots 100 \%$ more in compare with the cation exchanger KU-2-8. The obtained capacity values of the studied sorbents do not correlate with the parameters of the porous structure and, probably, to explain these results expediently on the hypothesis of the surface complexation model on metal oxyhydroxides with the formation of innerand outer-sphere surface complexes $[17,18]$. Surface complexes formation during sorption of ions occurs as a result of water replacement in the hydrate shells of metal atoms into sorbate ions [19]. Thus, the capacity of sorbents for the anions should depend on the amount and a replacement speed of water molecules in aqua complexes of oxyhydroxides central atoms (i.e., depend on coordination number of the central atom and the potential energy of complexation for this atom with water molecules). Coordination number -6 (for zirconium is $6 \ldots 8$ ) is characterized for all the studied 
metals. According to Kossel, the complexation energy for the same coordination number decreases with increasing charge of the central metal and as a result a more stable complex is formed in the next series of metals $\mathrm{Zr}>\mathrm{Al}>\mathrm{Mn}$. At the same time, the rates of water ions substitution for the studied metals oxyhydroxides can be ranged $\mathrm{Mn}>\mathrm{Al}>\mathrm{Zr}$ [20]. Hence, the formation of more stable complex of zirconium oxyhydroxide with water with a less rate of water substitution confirms obtained values of sulfate ions sorption, and adding the oxyhydroxides of aluminum and manganese into the sorbent could increase the sorption of ions.

High capacity of studied sorbents towards $\mathrm{Fe}^{3+}$ ions can be explained by the formation of complex of ferric chloride with aquacomplexes of metal oxyhydroxides. At that, it results in binding of ferric chloride molecules and leads to rise of the solution $\mathrm{pH}$, and, as a consequence, to the additional hydrolysis of ferric chloride. Thus, the aqua- and hydroxocomplexes of $\mathrm{Fe}^{3+}$ are formed and they create the common hydroxo bond with the preformed complex. This leads to high values of $\mathrm{Fe}^{3+}$ ions adsorption. This is not observed during the absorption of sodium ions, because the sodium hydroxide is strong electrolyte, which does not form the persistent aqua and hydroxo complexes in water. And, the absorption of sodium ions is taking place due to displacement of a proton from aquacomplex of metal oxyhydroxide (zirconium, manganese, aluminum). Thus, it can be concluded that increasing of the adsorption value of $\mathrm{Fe}^{3+}$ ions by the obtained sorbents in $1.5 \ldots 2$ times compared with cation exchanger KU-2-8 is caused by coordination bonds between the adsorbed hydrated ferric chloride with the hydrated molecules of sorbent and the hydrolysis of ferric chloride.

Conclusions. Data of X-ray diffraction analysis and IR spectroscopy indicate the presence of evolved hydroxyl-hydrate cover with the active sites of Lewis and Bronsted at the surface of studied sorbents based on xerogels of zirconium, aluminum and manganese oxyhydroxide. The composite sorbents differ from single-component ones in larger specific surface: the add into zirconium oxyhydroxide structure aluminum or manganese oxyhydroxides leads to the significant increasing of the sorbents specific surface area - from 236 to $536 \mathrm{~m}^{2} / \mathrm{g}$.

The full static capacity towards $\mathrm{SO}_{4}{ }^{2-}$ ions for sorbent based on xerogel of $\mathrm{Zr}$ and $\mathrm{Mn}$ oxyhydroxides is 1.5 times higher than the industrial capacity of anion exchanger AN-221. Increasing of the zirconium oxyhydroxide concentration in sorbents leads to reduction of their sulfate ions capacity. The maximum iron ions capacity is observed in the sorbents containing zirconium oxyhydroxide, their capacity is $1.5 \ldots 2$ times higher than the capacity of industrial cation exchanger KU-2-8. At the same time, $\mathrm{Na}^{+}$ions sorption does not depend on sorbent composition. Full static capacity of the samples is $1.56 \mathrm{mmol} / \mathrm{g}$ for the xerogel of $\mathrm{ZrO}(\mathrm{OH})_{2}$ and $\mathrm{AlO}(\mathrm{OH})$ without additives; 1.47 and $1.5 \mathrm{mmol} / \mathrm{g}$ for the sorbents that based on of zirconium oxyhydroxide doped of aluminum oxyhydroxide and aluminum and manganese oxyhydroxides, respectively. There is no correlation between the parameters of the adsorbents porous structure and their sorption properties. And probably the anions and polyvalent cation removal process is associated with the surface complexation at the metal oxyhydroxides.

Based on these data it can be concluded that the proposed method is effective for sorbents production based on xerogels of zirconium, aluminum and manganese oxyhydroxides for further use them to remove both polyvalent anions and heavy metals from aqueous solutions.

\section{Література}

1. Вергун, О.М. Аналіз актуальних чинників погіршення якості джерел питного водопостачання в контексті екологічної безпеки України / О.М. Вергун // Екологічна безпека та природокористування. - 2014. - Вип. 15. - С. $22-30$.

2. Долина, Л.Ф. Сточные воды предприятий горной промышленности и методы их очистки / Л.Ф. Долина; ред.: П. Хазан. - Д.: Молодеж. комиссия УЭА «Зел. світ», 2000. — 42 с.

3. Касимов, А.М. Перспективные процессы переработки и утилизации некоторых отходов производства минеральных удобрений / А.М. Касимов, Е.Е. Решта // Восточно-Европейский журнал передовых технологий. — 2011. - № 4/6 (52). — С. $66-70$.

4. Barakat, M.A. New trends in removing heavy metals from industrial wastewater / M.A. Barakat // Arabian Journal of Chemistry. — 2011. - Vol. 4, Issue 4. — PP. 361 - 377. 
5. Exceptional arsenic (III,V) removal performance of highly porous, nanostructured $\mathrm{ZrO}_{2}$ spheres for fixed bed reactors and the full-scale system modeling / H. Cui, Y. Su, Q. Li, et al. // Water Research. 2013. - Vol. 47, Issue 16. - PP. 6258 - 6268.

6. Zirconium doped nano-dispersed oxides of Fe, Al and $\mathrm{Zn}$ for destruction of warfare agents / V. Štengl, V. Houšková, S. Bakardjieva, et al. // Materials Characterization. — 2010. — Vol. 61, Issue 11. PP. $1080-1088$.

7. Shan, C. Efficient removal of trace arsenite through oxidation and adsorption by magnetic nanoparticles modified with Fe-Mn binary oxide / C. Shan, M. Tong // Water Research. — 2013. — Vol. 47, Issue 10. - PP. $3411-3421$.

8. Zhang, G. Simultaneous removal of arsenate and arsenite by a nanostructured zirconium-manganese binary hydrous oxide: Behavior and mechanism / G. Zhang, A. Khorshed, J. Paul Chen // Journal of Colloid and Interface Science. - 2013. - Vol. 397. — PP. 137 - 143.

9. Сорочкина, Е.А. Исследование характеристик пористой структуры сорбентов на основе гидратированных оксидов циркония и алюминия / Е.А.Сорочкина, Р.В.Смотраев // Пр. Одес. політехн. ун-ту. - 2013. - Вип. 3(42). - С. 253 - 256.

10. Перевощикова, Н.Б. К вопросу о гидролизе ионов железа(III) в водных растворах / Н.Б. Перевощикова, В.И. Корнев // Вестник Удмуртского университета. Серия «Физика и химия». - 2006. - № 8. - С. $189-198$.

11. Чалый, В.П. Гидроокиси металлов (Закономерности образования, состав, структура и свойства) / В.П. Чалый. - К.: Наукова думка, 1972. — 160 с.

12. Evaluation of the acid properties of porous zirconium-doped and undoped silica materials / D. FuentesPerujo, J. Santamaría-González, J. Mérida-Robles, et al. // Journal of Solid State Chemistry. — 2006. — Vol. 179, Issue 7. — PP. 2182 - 2189.

13. Эволюция гидратной оболочки гидроксида системы $\mathrm{ZrO}_{2}-3 \% \mathrm{Y}_{2} \mathrm{O}_{3}-x \mathrm{OH}_{n}$ в условиях высокого гидроскопического давления / О.А. Горбань, С.А. Синякина, С.В. Горбань и др. // Наносистеми, наноматеріали, нанотехнології. — 2009. - Т. 7, № 4. - С. $1195-1199$.

14. Кислотно-основные свойства поверхности сферически гранулированных сорбентов на основе гидратированных оксидов циркония и алюминия / Е.А. Сорочкина, Р.В. Смотраев, Ю.В. Калашников, Е.В. Груздева // Вопросы химии и химической технологии. — 2013. — № 6. - C. $102-104$.

15. Сорочкина, Е.А. Исследование электроповерхностных свойств сорбентов на основе гидратированных оксидов циркония и алюминия / Е.А. Сорочкина, Р.В. Смотраев // Вестник БГУ. Сер. 2. - 2014. - № 2. - C. $20-25$.

16. Strong adsorption of phosphate by amorphous zirconium oxide nanoparticles / Y. Su, H. Cui, Q. Li, et al. // Water Research. - 2013. - Vol. 47, Issue 14. — PP. 5018 - 5026.

17. Печенюк, С.И. Исследование сорбционных свойств аморфных оксигидроксидов металлов по отношению к анионам / С.И. Печенюк // Вестник Кольского научного центра РАН. — 2013. № 3. - С. $20-34$.

18. Печенюк, С.И. Сорбция анионов на оксигидроксидах металлов (обзор) / С.И. Печенюк // Сорбционные и хроматографические процессы. - 2008. - Т. 8, Вып. 3. - С. $380-429$.

19. Печенюк, С.И. О природе сорбционного комплекса на поверхности оксигидроксидов металлов / С.И. Печенюк, Л.Ф. Кузьмич // Сорбционные и хроматографические процессы. — 2008. — Т. 8, Вып. 5. - С. $779-789$.

20. Исследование кинетики совместной сорбции ионов индия и железа на полифункциональном катионите / К.Л. Тимофеев, А.В. Усольцев, С.С. Набойченко, Г.И. Мальцев // Вестник Омского университета. - 2015. - № 3(77). — С. $55-61$.

\section{References}

1. Verhun, O.M. (2014). Current analysis of factors deterioration in the quality of drinking water sources in the context of environmental safety Ukraine. Ecological Security and Nature Use, 15, 22 - 30.

2. Dolina, L.F. (2000). Waste Water of Mining Industry and Methods of Its Treatment. Dnipropetrovsk: "Zelenyi Svit".

3. Kasimov, A.M., \& Reshta, E.E. (2011). Promising treatment processes and waste disposal of certain production of mineral fertilizers. Eastern-European Journal of Enterprise Technologies, 4(6), 66 - 70. 
4. Barakat, M.A. (2011). New trends in removing heavy metals from industrial wastewater. Arabian Journal of Chemistry, 4(4), 361 - 377. DOI:10.1016/j.arabjc.2010.07.019

5. Cui, H., Su, Y., Li, Q., Gao, S., \& Shang, J.K. (2013). Exceptional arsenic (III,V) removal performance of highly porous, nanostructured $\mathrm{ZrO}_{2}$ spheres for fixed bed reactors and the full-scale system modeling. Water Research, 47(16), 6258 - 6268. DOI:10.1016/j.watres.2013.07.040

6. Štengl, V., Houšková, V., Bakardjieva, S., Murafa, N., Maříková, M., Opluštil, F., \& Němec, T. (2010). Zirconium doped nano-dispersed oxides of $\mathrm{Fe}, \mathrm{Al}$ and $\mathrm{Zn}$ for destruction of warfare agents. Materials Characterization, 61(11), 1080 - 1088. DOI:10.1016/j.matchar.2010.06.021

7. Shan, C., \& Tong, M. (2013). Efficient removal of trace arsenite through oxidation and adsorption by magnetic nanoparticles modified with Fe-Mn binary oxide. Water Research, 47(10), 3411 - 3421. DOI:10.1016/j.watres.2013.03.035

8. Zhang, G., Khorshed, A., \& Paul Chen, J. (2013). Simultaneous removal of arsenate and arsenite by a nanostructured zirconium-manganese binary hydrous oxide: Behavior and mechanism. Journal of Colloid and Interface Science, 397, 137 - 143. DOI:10.1016/j.jcis.2012.11.056

9. Sorochkina, K.O., \& Smotrayev, R.V. (2013). Investigation of porous structure characteristics of the sorbents based of hydrated zircon and aluminum oxides. Odes'kyi Politechnichnyi Universytet. Pratsi, 3, 253 - 256. DOI:10.15276/opu.3.42.2013.51

10. Perevotshikova, N.B., \& Kornev, V.I. (2006). On a question of iron(III) ions hydrolysis in aqueous solution. The Bulletin of Udmurt University: Physics \& Chemistry, 8, $189-198$.

11. Chalyi, V.P. (1972). Metal Hydroxides. Kyiv: Naukova Dumka.

12. Fuentes-Perujo, D., Santamaría-González, J., Mérida-Robles, J., Rodríguez-Castellón, E., JiménezLópez, A., Maireles-Torres, P., ... Mariscal, R. (2006). Evaluation of the acid properties of porous zirconium-doped and undoped silica materials. Journal of Solid State Chemistry, 179(7), 2182 — 2189. DOI:10.1016/j.jssc.2006.04.018

13. Gorban', O.A., Sinyakina, S.A., Gorban', S.V., Danilenko, I.A., \& Konstantinova, T.E. (2009). Evolution of hydrated shell of $\mathrm{ZrO}_{2}-3 \% \mathrm{Y}_{2} \mathrm{O}_{3}-\mathrm{xOH}_{\mathrm{n}}$ system hydroxide under high hydrostatic pressure. Nanosystems, Nanomaterials, Nanotechnologies, 7(4), $1195-1199$.

14. Sorochkina, E.A., Smotraev, R.V., Kalashnikov, Yu.V., \& Gruzdeva, E.V. (2013). Acid-base surface properties of granulated spherical hydrated sorbents on the base of zirconium and aluminum hydrated oxides. Issues of Chemistry and Chemical Technology, 6, $102-104$.

15. Sorochkina, E.A., \& Smotraev, R.V. (2014). Investigation the electrosurface properties of sorbents based on hydrated zirconium and aluminum oxides. Vestnik BSU. Series 2: Chemistry. Biology. Geography, 2, $20-25$.

16. Su, Y., Cui, H., Li, Q., Gao, S., \& Shang, J.K. (2013). Strong adsorption of phosphate by amorphous zirconium oxide nanoparticles. Water Research, 47(14), 5018 - 5026. DOI:10.1016/j.watres.2013.05.044

17. Pechenyuk, S.I. (2013). Investigation of sorption properties of metals amorphous oxyhydroxides with regard to anions. Herald of the Kola Science Centre of the Russian Academy of Sciences, 3, 20 - 34.

18. Pechenyuk, S.I. (2008). Anion sorption on metal oxyhydroxides. Sorbtsionnye i Khromatograficheskie Protsessy, 8(3), $380-429$.

19. Pechenyuk, S.I., \& Kuzmich, L.F. (2008). About the nature of sorption complex on the metal oxyhydroxide surface. Sorbtsionnye i Khromatograficheskie Protsessy, 8(5), 779 - 789.

20. Timofeev, K.L., Usoltsev, A.V., Naboychenko, S.S., \& Maltsev, G.I. (2015). Investigation of the kinetics of sorption joint indium ions and iron on a multifunctional cation exchange resin. Herald of Omsk University, 3, 55-61. 